\title{
Mocking fakeness
}

\section{Performance, phonetic aspiration and ethnic humour}

\author{
Mia Halonen and Sari Pietikäinen \\ The University of Jyväskylä
}

Phonetic resources, like dialects and accents, are used in ethnic humour to build up a recognisable character that pokes fun at the stereotypes associated with a particular identity, sometimes with critical and political undertones. In this article, we examine the manipulation of one such resource, aspiration, used in performing and mocking one such clichéd character, called the fake Sámi. This character has a contested history in Finnish tourism and marketing practices, and is embedded in a long-standing debate about who can use emblems of Sámi identity for economic purposes. Adopting a sociophonetic language regard and folk linguistics approaches (Preston 2010; Niedzielski \& Preston 2003) we explore how "fakeness" is constructed phonetically by the actors performing "Fake Sámi" in an indigenous Sámi television comedy show during a period of intense political debate in Finland over the legal definition of the category of indigenous Sámi. By analysing the use of hyperbolic aspiration of a prominent feature of Lappish Finnish dialect, the non-initial syllable /h/-sound, we show how the fakeness is performed by evoking linguistic stereotypes of a Finnish Lappish dialect and a Finnish English accent by a deliberate misuse of aspiration: aspirating when standard phonemes in speech should not be aspirated and not aspirating when phonemes should be aspirated. We argue that this kind of deliberate ambivalence and misuse of phonetic resources is a phonetic resource for reflexive postmodern identity performances.

Keywords: humour, comedy show, phonetic resources, aspiration, performance, media discourse, indigenous Sámi

\section{Introduction}

Dialects and accents, and more specifically the prominent phonetic features essential to them, are among the typical resources used in jokes about social identities related to ethnicity, gender and class. They are used to build up a recognisable, clichéd character that pokes fun at the stereotypes and categories associated with a 
particular identity, sometimes with critical and political undertones. The "real" or "fake" social categories are simultaneously typical yet contested sources of humour in many current television shows. Not only are they used for laughter, but they can also potentially stir-up the ideological process underlining the fixed views on social identities and relationships (cf. Hutcheon 2000 [1985]). With laughter, the viewer can decide whether to interpret the mediated performances as merely entertainment, or as critique (cf. Pietikäinen 2014).

This article focuses on accent performances of one such clichéd character, called the fake Sámi, a persona that tries to pass as an authentic member of the indigenous Sámi community for economic purposes, typically to be found operating in a tourism context in Finnish Lapland. The transnational indigenous Sámi community comprises of estimated 60.000-100.000 people. There are nine Sámi languages in all, of which Northern Sámi has the highest number of speakers (c. 30,000), while the other Sámi languages have as few as 250-400 speakers each (Aikio-Puoskari 2005; Kulonen, Seurujärvi-Kari \& Pulkkinen 2005). They are legally recognized indigenous languages in Norway, Sweden and Finland, with acknowledged rights and resources at least in the Sámi homeland area, often referred as Sápmi. They are the focal points of Sámi politics and of certain well-defined cultural practices (see, e.g., Lehtola 2015).

The fake Sámi character has a long and contested history in this context. S/he is embedded in a long-standing debate about who can use emblems of Sámi identity, including the Sámi dress, cultural artefacts, and languages for economic profit. The official view, articulated, for example, by the highest political Sámi institutions including the Sámi Parliament and the Sámi Council, condemn the use of Sámi resources by non-Sámi individuals and interest groups for economic or other purposes (see e.g. Magga 2012). Yet, Sámi emblems continue to be used by non-Sámi in tourism business as well as in popular culture, sport events and beauty pageants. The commodification of indigenous resources by a non-Sámi is considered to be at least politically incorrect, but also at times as a form of colonisation and exploitation (Länsman 2004). The issues of "fakeness" in the Sámi context have profound social and political implications. The contested boundary between what is perceived as "real" Sámi and as non-Sámi has continued to be a constant source of tensions (cf. e.g. Sarivaara 2012) and is currently under legal dispute between the Finnish Sámi parliament and the state of Finland (Lehtola 2015).

In this article, we explore how "fakeness" is conveyed phonetically and discursively in an indigenous Sámi television comedy show at a time of intense political debate in Finland over the legal definition of a category of "real" indigenous Sámi people and the right to use indigenous resources for economic profit. More specifically, we focus on how fakeness is constructed through the manipulation of a prominent phonetic feature of the Lappish Finnish dialects and of the Finnish English Tankero accent, namely that of aspiration. 
By focussing on perceptions of a phonetic feature as a resource for indexing linguistic varieties, our research aligns with the tradition of sociophonetics and language regard (e.g. Preston 2010), including folk linguistics (Niedzielski \& Preston 2003). The humorous value of the feature draws on their long history, and thus recognisability, in performances and discourses of stereotypes of Lappish, Sámi, and Finnish ways of speaking, now used in the context of the Sámi comedy, and in relation to perceived fakeness and realness. We focus on how the fakeness of a comedy character called fake Sámi is performed and how it evokes a linguistic stereotype of a Finnish Lappish dialect and the Finnish English accent by focusing especially on the manipulation of aspiration. By manipulation we mean the deliberate misuse of aspiration: aspirating when standard phonemes in speech should not be aspirated and not aspirating when phonemes should be aspirated. According to Bell and Gibson (2011), this type of deliberate misapplication of various phonetic features is a typical means in performances.

First, we will briefly discuss media performances of ethnic humour and aspiration as a key phonetic resource in sketching ethnic characters in TV humour. After that, we will concisely introduce the Sámi comedy show in question, and, more specifically our data: the fake Sámi skit. We will then first present the sociolinguistics of Finnish Lappish dialects and the Finnish English accent in order to show how it is possible that manipulating aspiration, through over- and underuse, can be used to sketch a stereotype of a Finn faking a Sámi. After that we will analyse this use of aspiration in the focus skit. Finally, we will conclude with a discussion of how fakeness is performed and why it has the potential to create post-modern humour on a TV comedy show.

\section{Phonetic resources in performing ethnic characters in TV humour}

In this article, we use the concept of performance to refer to presentations that are reflexively and culturally-bound by semiotic resources similarly understood both by performers and their audience(s). According to Bauman and Briggs (1990, 73), performances put the act of speaking on display for the audience(s) to recognise and appreciate. This reflexive character of performance opens up an ambivalence that is strategically employed in many of the current TV comedy shows. For example, Holm (2011) argues that there has been an increase of new mediatised humour that is concerned with the explicit disruption and transgression of social boundaries in order to engender shock and laughter. This carnivalesque mood (Bakhtin 1984 [1965]; Pietikäinen 2015) with its emphasis on an upside-down world and subversion is embraced in many instances of mediatised humour (McDonald 2010). The popularity of TV comedy shows such as South Park, The Simpsons, Jackass and Little 
Britain indicate that their humour attracts audiences through ambiguity, reflexivity, transgression and ridicule of the "official" discourses, even though they can also have the effect of reinscribing dominant discourses.

Similarly, the Sámi TV comedy show under scrutiny in this article can be located within this realm of humour. The Märät Säpikkäät/Njuoska Bittut TV comedy show can be seen as an example of postmodern humour for its complex and controversial critique on stereotypes and seemingly fixed positions, while at the same time drawing attention to the fact that the stereotypes being ridiculed are also used to perform the critique. The ambivalence relates especially to the directionality and intentionality of the humour: who is laughing at whom and at what? The ambivalence of the postmodern humour blurs boundaries between the official and the vernacular, as well as the boundaries of moral order. This ambivalence is also interpreted differently. While there have been some concerns about issues such as good taste (moral order) and the appropriate ways to publicly represent Sámi issues, the show appeals to a "smart" niche audience who derive pleasure from their ironic cleverness and postmodern sensibilities and self-reflexiveness.

Mediated performances of social identities have been examined from a number of perspectives in sociolinguistics and linguistic anthropology (see, e.g. Bauman and Briggs 1990; Coupland 2007; Johnstone 2011; Pietikäinen 2015). If we zoom in to the linguistic resources used to perform ethnic humour linguistically, the key role of mocking a dialect or an accent becomes quickly apparent. Already Goffman noticed the relationship between mocking and stereotyped characters in arguing (1981, 150): "we can mock an accent or dialect, projecting a stereotyped figure more in the manner that stage actors do than in the manner that mere quotation provides". Several studies have picked up this interest. For example, Hill (1995) shows how junks of linguistic resources are used to mock Spanish and its speakers. The same kind of out-group mocking has been done with varieties of AAVE and Ebonics studied by Ronkin and Karn (1999) and later for example Bucholtz and Lopez (2011) who show how performances of Blackness by European American actors in Hollywood films are heavily based on Mock African American English - that is, on an exaggerated use of the most stereotypical phonetic features of that variety. This exaggeration acts not only as parodic performance, but adds a dimension that arises from the historical trajectories of "blackface shows".

In the context of humour performances in media, Mühleisen (2005) studied the ambivalent humour of Black English "accents" in television. She argues that the ability to convey humour arises not from the accent itself, but from its power to evoke the characteristics stereotypically associated with that group. Similarly, Sebba (2007) examines the ability of an accent, or a cluster of phonetic features, to evoke stereotypes as in the resources that actor Sacha Baron Cohen uses to create the "Jafaican" speaking character "Ali G" in television shows and movies. In addition 
to the so-called ethnic varieties and accents, local dialects and varieties are used as resources for performing stereotypes. The stereotypes related to various localities inside one language are plentiful, and a typical source of humour.

This article examines one particular linguistic resource in performing ethnic humour, namely the phonetic feature of aspiration. We suggest that the manipulation of this feature is one of the core means by which the TV comedy audience is invited to evaluate the performance and to "get the joke" or even laugh at it. Drawing on Johnstone's illustration of reflexivity $(2011,676)$, we could say that the actors in this particular case are not only asking "what does it mean that I am saying these words?", but also "what does it mean that I am saying these words like this?". Even though we believe that manipulating the aspiration is a key linguistic resource used in the skit, we do not know whether it is a conscious choice as aspiration is not necessarily an "overtly available feature" (Preston 1996) that non-linguists, including the actors, could pick up on or describe. These types of widely-known stereotypical features are however often imitable. Whether it is conscious or not, we claim that the aspirations and the lack of them that the actors perform are recognisable as indexing Lappish Finnishness. In order to support this claim we will draw on dialectological knowledge of the languages and varieties in play, as well as folk linguistics (Niedzielski \& Preston 2003). Beyond the auditory and acoustic analysis of phonetic variables, our analysis draws on the shared perceptions of sociolinguistic features.

\section{Data: Fake Sámi skit in a TV comedy show}

Our data focuses on a multilingual, indigenous television comedy show called Märät Säpikkäät/Njuoska bittut. Its two seasons were broadcasted on the Finnish national television channel (YLE 2) from 2011 to 2013 in prime-time and it retained a considerable audience of approximately 250,000 viewers - a large number in Finland, which has about 5.4 million inhabitants. The show's main source of laughter is the stereotypes related to indigenous Sámi people, as well as to the Finnish majority. The show is a 30-minute programme of skits, based on jokes and mocking parodies of various well-known television formats, with recognisable albeit exaggerated characters from both Sámi and Finnish contexts. The programme alternates between Finnish language and Northern Sámi languages, but English and Swedish are also occasionally used. It is produced and performed by two young multilingual Sámi women, both experienced and acknowledged professionals working in various cultural and media environments. Their Sámi status gives them the authority and legitimacy to joke about Sáminess - a practice that would very easily be seen as offensive otherwise (cf. Pietikäinen, Kelly-Holmes, Jaffe 
\& Coupland 2016). Nevertheless, public discussions about the programme revealed mixed reviews by both the Sámi community and Finnish audiences. These reactions ranged from finding the show hilarious and entertaining, to finding it insulting, perpetuating old stereotypes and diminishing Sámi culture (see Pietikäinen 2014 for a more detailed presentation of the show).

In a particular skit a character called fake Sámi attempts to pass as an authentic Sámi for tourists. This attempt and the ways in which Sámi resources are used for profit in the tourism industry are consequently ridiculed. This skit belongs to a string of similar kinds of skits, each introducing a stereotypical character in Sámiland (e.g., a SuperSámi, a tourist, a city person, etc.) in each episode (for further discussion of the skits see Pietikäinen, Kelly-Holmes, Jaffe \& Coupland 2016). These stereotypes are familiar both to Sámis and Finns. As Lockyer $(2010,123)$ notes, stereotypes as a representational strategy are often used in television comedy to ensure recognition and appropriation. In mocking, an act, habit, or figure is ridiculed and is made a target of critical, witty commentary. In Märät Säpikkäät/ Njuoska bittut, the figure that is being mocked is that of the fake Sámi, whose act of using Sámi resources for tourist purposes is ridiculed and critically commented on. The fake Sámi figure embodies much of the controversy related to the commodification of Sámi resources for tourism (cf. Pietikäinen 2015; Pietikäinen, Kelly-Holmes, Jaffe \& Coupland 2016).

The skit begins with a scene in front of a tourist shop, where the fake Sámi is performing for passing tourists and trying to sell them her products - reindeer antler powder as a supposed aphrodisiac. In the subsequent scene, in a mock interview, the fake Sámi is interviewed about her right to use Sámi symbols. In the final scene, the fake Sámi continues to perform for the tourists. The skit is narrated by a Finnish-speaking female voice, belonging to one of the presenters, and she provides both background and commentary on the actions of the fake Sámi. A transcript of the whole skit is found in the Appendix at the end of this article.

\section{Finns faking Sámis: About the context of fake Sámi discourse}

The term fake Sámi has a vernacular value in, for example, Finnish social media discussions about people and activities related to tourism and indigenous culture in Sámiland. In the local context of northern tourism in general, it refers to Lapland tourism service providers, Finns, who are not considered to belong to the Sámi community, and who are not seen to have Sámi heritage, but who, nonetheless, use Sámi resources in their products and performances. These resources include for example Sámi colours from the Sámi flag, Sámi ornaments, Sámi dresses, Sámi 
languages, and other Sámi cultural practices, such as joiking, the northern Sámi traditional singing, and the shamanistic drum.

Comedy character types need to be easily recognisable and understandable if viewers are to be enabled to appreciate the jokes. Thus, comedy characters often draw on wider sociocultural beliefs and assumptions about specific people and individuals. The characters are funny not just because of the way they interact, but also because they are individually related to wider dominant social assumptions and understandings of the topic at hand (Lockyer 2010, 123). The indexes of semiotic fakeness, of the fake Sámi and the spatial location of the character, are stereotypical in the sense that these features and location are recurrently discussed and debated in public discourse. In the Märät Säpikkäät/Njuoska Bittut version, the fake Sámi is performed by one of the presenters, playing the role of a young female tourist worker and wearing a mock version of the Northern Sámi dress. She has a "toy" Sámi drum (very small in comparison to authentic drums) and performs the stereotypical tourist workers' activities: performing for tourists, selling products to tourists, and defending her rights to use Sámi resources in her work. The activities of the fake Sámi are located in one of the largest tourism resorts in the area, which attracts national and international tourists. With these choices of semiotic resources, the discursive construction of the fake Sámi in the comedy show is located within the debate of using Sámi resources in Lapland tourism and the question of authenticity (Pietikäinen 2014).

The fake Sámi skit displays many of the stereotypes that circulate in Lapland tourism about Sámi people: the nomadic way of living (see, the Appendix, line 1, I live in a tepee with reindeers), the sexualisation of the indigenous Sámi people (line 10, potency much potency Sámi mystical power; line 15, reindeer antler powder; line 16, Sámi virility), and the shamanism (line 21, we'll put a spell on all our enemies). The embodied, materialized stereotypes include dressing up as a Sámi (lines 4-7) and performing cultural practices perceived as iconic to Sáminess (joiking, playing the shamanistic drum), thus mocking the attempts of the fake Sámi to sell products and services that are not part of her own cultural heritage. The fakeness is also underlined by listing the places that one can meet fake Sámi in the narrator's story: in beauty contests, tourist traps, travel fairs, and as a grid girl in motor races (lines 2-3). These all are commercial sites where Sáminess is used to promote marketing and sales. Finally, in the mock interview, the fake Sámi compares Sámi cultural resources to natural resources, which are, to an extent, free for use by all Finnish citizens. However, the main resource used to mock the fakeness is the use of the exaggerated dialect and accented talk, to which we now turn. 


\section{Manipulating aspiration as the resource of performing a Finn faking a Sámi}

In order to be able to understand how phonetic aspiration can function as a resource in the performances in the skit, one has to have the whole picture of the status of aspiration in this specific context. First, there are (default) phonetic systems of Finnish and English in the skit. To summarize the systems briefly, capturing only the rules relevant to understand the phonetic play in the skit, we can say that there are no aspirated sounds in Finnish, whereas in English the word-initial plosives are always aspirated (Ogden 2009, 96-103).

In addition to these (standard) languages, the play also includes Lappish Finnish dialects and the Finnish English accent, in vernacular called Tankero. In Lappish Finnish dialects, as in standard Finnish, there are no aspirated phonemes. But, unlike standard Finnish, there are however, "additional" /h/-sounds in specific non-initial syllables. Finnish listeners coming from outside of this Lappish Finnish dialect area perceive this feature as general "h-ness", which again can be and is often imitated through hyperbolic aspirating. In turn, in the Finnish English accent, all the aspirations belonging to English phonology are dropped. Hence, in order to perform a Lappish Finn, the actors use hyperbolic aspiration when they speak Finnish and drop all aspiration when they speak English. Figure 1 illustrates this dynamic use of aspiration as a resource in the performance.

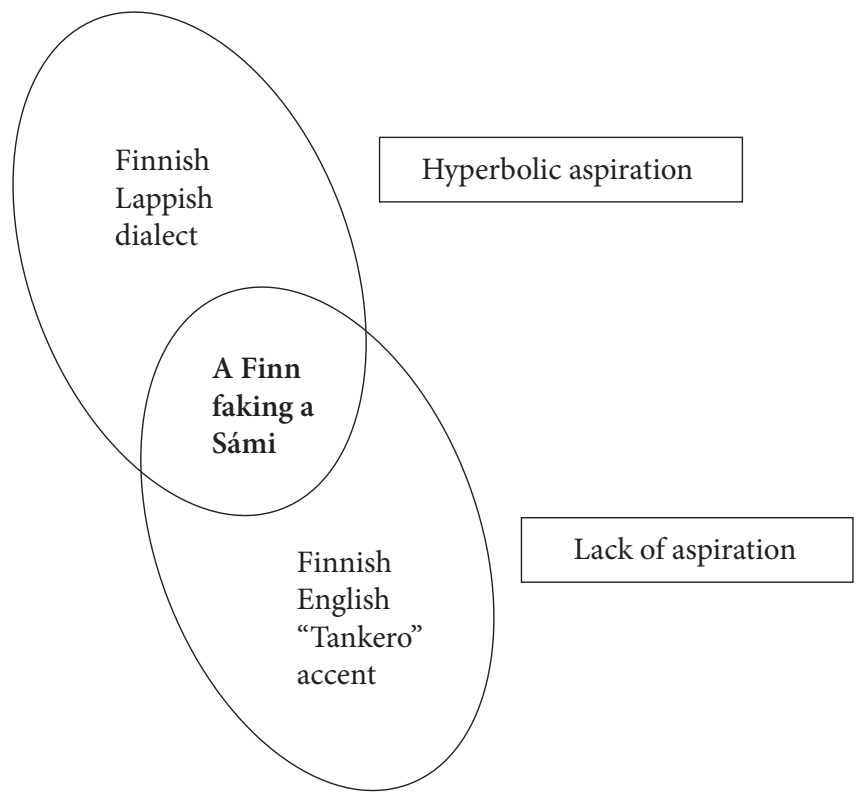

Figure 1. Aspiration as a nexus resource for enacting a native Finn faking a Sámi. 
Next we will analyse in more detail this resource used in the skit, starting with the performance of a Lappish Finnish dialect. After the empirical analysis, we return to the core question of the function of this manipulative resource, that is, what is it that makes performing a Finn faking a Sámi humorous in this context.

\subsection{Hyperbolic aspiration in performing a Lappish Finnish dialect}

The most prominent and exclusive morphophonetic feature of the Lappish Finnish dialects is called "speaking on top of $h$ ". This "h-ness" is a feature of the different variants of the Lappish Finnish dialect, while, at the same time, it does not exist in any other dialect of Finnish. For example, the standard Finnish word jokainen ('everyone') is jokhainen in the Lappish Finnish dialects. For our argument here, it is important to observe that h-ness is in no way related to aspiration. It is an additional /h/-sound (a pharyngeal or glottal fricative) in the second syllable, and not a manner of articulation like aspiration is. The specific place of the $/ \mathrm{h} /$ in the second syllable varies considerably depending on the dialects. (For the history, development and the variation of this feature, see Mantila 1992.)

Even though the feature is linguistically predictable, because of its complexity it is perceived by outsiders as simply a random addition of an /h/-sound here and there, thus as a general h-ness. (For more on the perceptions of this feature as an index of Lappish Finnish dialects, see Mielikäinen \& Palander 2014; Vaattovaara 2012.) The h-ness of Lappish dialects is hence both a linguistic fact - there really are acoustically more /h/-sounds than other dialects in Finnish - and a folk linguistic fact (Preston 2002), a perception of general h-ness. Furthermore, for a speaker non-native to the dialect, it is extremely difficult to put the sound $/ \mathrm{h} /$ in an accurate place in a word or even in the second syllable. Consequently, when non-native dialect speakers, including actors, perform it, they do it through aspirating. This is possible because aspiration is often perceived by hearers as an " $h$-like additional sound" because in both aspiration and the /h/-sound, the vocal tract is open (Iivonen 2009, 58-59).

Similarly, in our focus skit, h-ness is performed by aspiration. In Excerpt (1), for example, the actor who performs a fake Sámi introduces herself as "a girl from a fell" to tourists in a parking lot of a local supermarket. In the transcriptions below, the first line in square brackets represents a phonetic transcription in International Phonetic Alphabet (IPA) script, with aspirations marked by a superscripted $h\left({ }^{\mathrm{h}}\right)$. The second line is written in IPA in Lappish Finnish dialect to illustrate the frequency of the aspirations. Comparing these two, it can be seen that the aspirations do not correspond to any authentic placement of $/ \mathrm{h} /$ sound - in these clauses there would be no /h/ sounds in Lappish dialects. The third line is an English written translation or paraphrasing. 
(1) [mie olen Sa:na $t^{h} y t:^{h} \varnothing t^{h} u n t^{h} u_{i i s t}{ }^{h}$ ]

Mie olen Sa:na, tyt:hø tunturista.

'I am Saana - a girl from the fell.'

[mie elæn porojen $k^{h}$ ans:a $k^{h}$ odas:a]

Mie elæn porojen kans:a kodas:a.

'I live in a tepee with reindeers.'

Later in the skit:

[ $k^{h} u n$ me $s^{h} u: t^{h} u m: e ~ m e ~ k^{h}$ iroam:e $k^{h}$ aik:i vihol:ishem:e.]

Kun me suutumme, me kiroamme kaikki vihollisemme.

'When we get angry, we'll put a spell on all our enemies.'

The frequent use of aspiration in such a short speech extract performs the general h-ness of the Lappish Finnish dialect. The use of h-ness in performing Lappish people has a somewhat long tradition in Finland, which can be seen in the history of Finnish television comedy, especially when imitating Sámi people. One example of this is the TV comedy Pulttibois, a very popular series broadcasted from 1989 to 1991 on the Finnish national television station, consisting of repeated and recycled skits. Excerpt (2) presents the start of the skit repeated in every skit about Sámi men: first "joiking", a traditional Sámi form of singing, and then a vague reference to the "happy savage" image of Sámi people loving to sing and dance. Again, we can see that the aspirations to not correspond the placements of possible /h/-insertions; only possible place marked with bolded h in the Finnish Lappish dialect gloss (the second line in the transcription).

(2) Men together: [nun:uk $k^{h}$ nun:uk $k^{h}$ loil:a: loil:a: nun: $u k^{h}$ a nun:uk $k^{h}$ loil:a: loil:a:] ((Untranslatable joiking or singing))

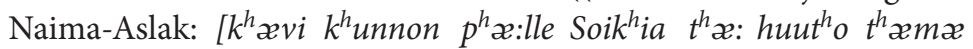
Kävi kunnon päälle Soikia tää huuto tämä iænikune jorh:aamine] iänikhune joraamine

'This really got me Soikia this shouting this forever ongoing dancing'

As the short example illustrates, the singing and speech of the Nunnuka-men is loaded with aspirations. The skit presents two highly stereotyped figures of Sámi men, named Soikiapää (which could be paraphrased as 'Ovalhead' in English) and Naima-Aslak ('Shagger Aslak'), and their mocking version of traditional Northern Sámi singing, joiking: nunnuka nunnuka loilaa loilaa.

Thus, more than 25 years ago, in Pulttibois skits, Sáminess was performed linguistically with exactly the same phonetic resource, the use of aspiration, for 
performing h-ness and the Lappish Finnish dialect (see also Dlaske \& Jäntti 2016 on "doing Lappish" and this intertext for contemporary media humour). Next, we examine a "mirror image" resource in the performance: the underuse or lack of aspiration when speaking English with a Finnish accent.

\subsection{Lack of aspiration in performing a Finnish English "Tankero" accent}

In the Märät Säpikkäät/Njuoska bittut skit, speaking English with Finnish accent is also a resource to create humour by performing typical tourist activity in Lapland: selling Sámi products. The questions of why and how this performance is considered humorous in this context will only be addressed in the next section. In what follows, we will explore the role of manipulating aspiration in performing this variety and its stereotypical speaker, a Finn. Whereas aspiration is used in performing Lappish Finnish dialect, the default aspirations in word initial plosives $(/ \mathrm{p} /, / \mathrm{t} /, / \mathrm{k} /)$ in English (see Ogden 2009, 96-103) are left out in performing a Finnish English Tankero accent, just like the ungrammatical placements of the aspirations were used to show that the character is fake, only pretending speaking the dialect, also the lack of aspirations constructs the character being a Finn - not a Sámi.

Leaving out aspiration is such a prominent feature that only a very short segment of speech is needed to convey the effect, as illustrated in the next Excerpt (3). In the first line, the original speech [Tankero] is transcribed in IPA. The second line is also in IPA for standard English and the sounds that are normally aspirated - but lack from the Tankero - are marked with a superscripted $h\left({ }^{\mathrm{h}}\right)$. In the third line, there is a paraphrase of the original in orthographic English.

(3) [o:ko: ten ten euro]

$o: k o: t^{h}$ en $t^{h}$ en ju:ro

'okay, ten, ten euro'

In Excerpt (3), we can see the phenomenon in the word ten which is pronounced [ten] without an aspirated / $t /$. As can be interpreted from the very short extract, the variety is quickly and easily outlined, mainly with the lack of aspiration which is easily recognisable and highly marked for native English speakers as well as Finns knowing any English. Hence, similar to the h-ness discussed above, the lack of aspiration in a Tankero English accent is an easily recognisable resource for all Finns.

The lack of aspirated word-initial plosives is the most prominent feature of the variety - which is shown also in its common name, Tankero. a folk linguistic name for a linguistic variety made popular in the 1970s by the time of Finnish Prime Minister Ahti Karjalainen. In Finland, he was famous for speaking English with a strong Finnish accent. The very name of the accent comes from an anecdote of the 
minister having pronounced the word 'dangerous' as [tankerous] (in IPA conventions for standard English), which shows that along with a lack of aspiration there are also various other prominent features included in the accent, such as de-voiced /d/ and despirantized /g/-sounds. In Finland, Tankero has a high vernacular value as a folk linguistic fact (Preston 2002), and the term is used by Finns themselves to mock their own accent - it is a domestic name for "bad English". It is important to note, however, that not every Finn speaks Tankero English. When it is performed, it is mostly used to index a relative lack of cosmopolitanism and related language skills, and, consequently, to index a stereotype of "uneducated non-international" common people. Nevertheless, Tankero English has recently been also used to create a lighter, humorous, self-reflexive tone for example in a television commercial (in 2014 and 2015) promoting the new motor sports season with the motto Rällienglish is bäk ('Rally English is back'), written in a way that echoes a Tankero English accent and refers to the English pronunciation of some famous Finnish drivers, like Mika Häkkinen or Tommi Mäkinen. Hence, the term currently has a positive echo as well: these professionals are international cosmopolitans who made their career outside of Finland and often "in English", despite their accent.

In our analysis here, we have shown how the manipulation of aspiration appears as a resource of outlining a stereotype of an ethnic Finn. We find the skit to be an example of an extremely sensible understanding, whether conscious or subconscious, of how the smallest linguistic features (in relation to duration and overt availability) index a whole class and ethnic group of people. We also argue, that aspiration is so productive because it is a phonetic feature non-existent in the system of Finnish; leaving it "free" to gain only or primarily social meanings (Vaattovaara \& Halonen 2015). Furthermore, based on even the short history of similar uses of the resource in similar contexts and comedy genres, we argue that manipulating aspiration has conventionalised into a reflexive index of not only the varieties discussed above, but also of Finnish comedy performances. It functions thus not only as a marker of a Lappish Finnish dialect and a Finnish English Tankero accent, but it also puts the very use of language on display and indexes a comedic genre and performance. By this we also suggest that this resource might have developed into an obligatory part of this kind of performance. Drawing on linguistic anthropology, we argue that aspiration has been schematised and entextualised as part of the comedy genre in Finland, and performances of a Lappish Finn, through the production, reception, and circulation of particular orders of texts and for the production of intertextuality.

Aspiration as a resource is necessarily intertwined with other semiotic means of performing the stereotype and conveying humour in the skit. This intertwining will be examined in the following section when discussing what it is that makes this ethnic stereotype humorous. 


\section{Ambiguous fake Sámi humor}

Above we have shown how manipulating phonetic aspiration can be used as a resource to perform a stereotype of an ethnic Lappish Finn in a Finnish television comedy. What we have not yet addressed is how this type of performance can be humorous in this context.

Like the name of the skit suggests, the main aspect of the humour lies in the work done by a Sámi actor performing a Finn who is performing a fake Sámi. In the skit, fakeness is performed in multiple ways. Firstly, it is explicated in the commentary by explicitly naming the character fake Sámi. In the skit, this discourse is commented on by young indigenous Sámi women actors laughing at the Finnish majority and their attempts to pass themselves off as indigenous Sámi. This act of "turning the tables" can be seen as a form of reflexive textual intervention (Pope 1995) in a postcolonial context, and has the potential of altering and subverting traditional ways of representing and seeing minority - majority relations. At the same time, in a spirit of post-modern humour in general, the skit can also be seen as laughing at the Sámi minority and its prejudices and fears. The performances of fakeness are simultaneously typical yet contested sources of humour, related to an ongoing power struggle and legal debate over the definition of the category of Sámi. The contested boundary between what is perceived as "real" Sámi and as non-Sámi has continued to be a constant source of tensions (cf. e.g. Sarivaara 2012), and the commodification of indigenous resources by a non-Sámi is considered to be politically incorrect, or even a form of colonisation and exploitation (Länsman 2004).

The whole semiotics and discursive practices of the skit work together to enact the stereotype. As seen in Section 3 above, the embodied, materialised stereotypes include dressing up as a Sámi and performing cultural practices perceived as iconic to Sáminess. The fake Sámi wears a mock, inauthentic version of the Northern Sámi dress and plays a toy Sámi drum, which is actually very small in comparison to authentic drums. Furthermore, the Sámi is presented as a young female tourist worker performing stereotypical tourist worker activities: selling products to tourists and performing to them. Together with the creation of an impression of the Lappish Finnish dialect, the skit displays all the crude stereotypes circulated in Lapland tourism about Sámi people and through exaggeration mocks their nomadic way of life (I live in a tepee with reindeers), their shamanism (we will curse all our enemies), and sexualises them (much potency Sámi mystical power, Sámi virility) (see Appendix).

The skit takes place in one of the largest tourism resorts in the area, recognisable to viewers familiar with Lapland tourism. The indexes of Lappish Finnishness, conveyed by the manipulation of aspiration, serve to mock the fakeness and the out-of-placeness of the tourism products and practices offered by Finnish tourism 
service providers. Both the Lappish Finnish dialect and the Tankero English accent contributes to show that it is not a Sámi person speaking but a Lappish Finn, and ultimately, lacks a legitimate access to Sámi resources. The skit thus rests on, but also critically comments on, the tourism products and selling practices of the Finnish majority capitalising on indigenous Sámi culture and practices. This capitalisation is also shown in - at first glimpse - a careless attitude towards the protagonist's identity by changing her name during a relatively short skit from Saana - a name of a fell in Sámiland associated with Sámi mythology - to Tiina, which is a typical Finnish name.

(4) Saana - or was it Tiina? Who cares?

[mie olen Sa:na $t^{h} y t^{h} \varnothing t^{h}$ unturist $^{h} a$ ]

Mie olen Saana, tyttö tunturista.

'I am Saana - a girl from the fell.'

Later in the skit:

$$
\begin{aligned}
& {\left[T^{h} i: n a t^{h} y t:^{h} \varnothing \text { tunt }^{h} \text { urist } t^{h}\right. \text { ] }} \\
& \text { Tiina tyttö tunturista. } \\
& \text { 'Tiina - girl from the fell.' }
\end{aligned}
$$

The fake Sámi skit examined here is thus tightly situated in the political discourse and debate over the legitimacy of Sámi identity, and makes critical yet humorous comments on this ongoing practice in Finnish Lapland tourism. In the skit, the fake Sámi is positioned in sharp contrast to a "real" Sámi, who has legitimate access to Sámi resources via family connections and community recognition. We argue that in the show, humour is used as a critical resource for reflecting on ethnic, sexual, gendered, and geographical stereotypes and categories, as well as a resource for legitimating this type of ironic stirring-up of ideological relationships and categorisation (cf. Hutcheon 2000 [1985]). The humour performance can also be used by the actors to mock Sámi protectiveness of their culture and heritage and in this way to destabilise essentialised notions of indigenous identity and language and the assume relations between them (cf. Pietikäinen, Kelly-Holmes, Jaffe \& Coupland 2016). Typical to post-modern TV-humour, mocking hits various target groups at the same time. Coupland (e.g. 2007, 171-176) argues that both in-group and out-group mocking is always reflexive in the sense that while it mocks the performed speakers, it at the same time mocks the performers doing the mocking. With laughter, the viewer can decide whether to interpret the programme as merely entertainment, or to see in it critical undertones. 


\section{Discussion}

In this article, we have argued that in performing a fake Sámi, that is, a Lappish Finn faking a Sámi, the actors in the show draw on the manipulation of one phonetic feature. By their hyperbolic aspirating, they are able to perform h-ness which is perceived as the most important and prominent feature of Lappish Finnish dialect as Lappish Finnish dialects have non-initial syllable /h/-sounds that do not exist elsewhere in Finnish. In turn, the total lack of aspiration allows the actors to perform a Finnish Tankero English accent, an accent variety exclusively Finnish. Together, by this manipulation of one phonetic feature, the actors are effectively able in a short skit to sketch a stereotype of a Lappish Finn faking a Sámi to gain profit out of traditionally Sámi heritage and resources. Also a Finnish English Tankero accent indexes a Finn and not a Sámi, which again highlights the fakeness of the character.

Aspiration as the means of performing h-ness has yet a longish history in Finnish comedy media. Along with h-ness functioning as an index of geographical locality, it has also gained social meanings reaching beyond its pure local referentiality (cf. Vaattovaara 2012). In Silverstein's (2003) terms of indexical order, the sound $/ \mathrm{h} /$ has gained a higher order indexicality, being able to alone evoke a perception of a Lappish speaker. Phonetic features indexing a place and a social category are recognised by audiences from the same culture who possess similar linguistic repertoires - even when they cannot tell what they base their interpretation on (cf. Dufva \& Halonen 2016). Thus, the phonetic indexes are not only linguistic facts based on research, but also folk linguistic facts, recognised and reproduced in lay discourses on language, drawing on Preston's (2002) concepts. After a semiotic sign has been indexicalised as a marker referring to some aspect of social reality, it can be taken consciously to be used as a resource for a performance, a stylisation (see, Coupland e.g. 2007; Rampton e.g. 2006; cf. Silverstein 2003).

Thus, stylisation and exaggeration intertwine in reflexive performances. Bauman $(2011,709)$ argues that, in performance, the reflexive focus is the formal organisation of the entextualised act of expression, rather than the word or sentence. Performing a stereotype of an essentially fake figure also exposes the illegitimacy of its action. Exaggeration of a phonetic feature is a means to create fakeness, but also means of commenting reflexively on the action being overdone, being a staged performance, which should be received as such. Hence, exaggerated performance reflexively marks the action as parody and mocking, and it connects with aspects of excessiveness and exaggeration in the postmodern comedy genre. Performing fakeness is also a way of doing reflexivity since it is inherently based on recognisable exaggeration and staging (Bauman \& Briggs 1990); one of the archetypes of humour is a loser who fails to be authentic. Hence, fakeness is a crucial ideological 
construction in discourses concerning the Sámi. (Cf. Bucholtz 2003, 408; Bucholtz \& Hall 2005; Kramsch 2012; Piller 2002, 181-182.) The reflexivity grows from mere parody into a meta-parody (cf. Bucholtz \& Lopez 2011), not laughing at the obvious target alone - that is, Finns performing Sáminess - but also reflexively at the Sámis themselves performing Finns performing fake Sámis (cf. Coupland 2007). With this double orientation, the skit links to the ongoing heated discussion of authenticities and categories within the Sámi community (see Pietikäinen \& al. 2016) in which various in-group member groups struggle over the right to Sámi identity.

The inherent ambivalence and double-voicedness of postmodern mediated humour is increasingly seen to be employed in many current television comedy shows. Holm (2011) argues that, from the beginning of this century, there has been an increase in a novel type of mediatised humour concerned with the explicit disruption and transgression of social boundaries, in order to engender shock and thereby laughter. This is further fuelled by employing the postmodernist mood - with its emphasis on doubt, chaos, and relativism - embraced in many instances of mediatised humour. The popularity of television comedy shows such as South Park, The Simpsons, Jackass, and Little Britain indicates that their humour - which contains ambiguity and the ridicule of "official" discourses intersects with the desires of the audience and also with current postmodern politics. The ironic focus on parody, ambiguity, and absurdity creates a space that is organised around the order of playfulness, enabling reflection and critique of the constraints of the official orders - be they political, religious, or other (Pye 2006). As Olsen $(1990,19)$ argues, the appeal of postmodern humour is that it undermines hierarchy and absolutist discourse and is comfortable with chaos and plurality and very much based on activity of mocking. In mocking, an act, habit, or figure is ridiculed and is made a target of critical, witty commentary. As Bakhtin (1984 [1965], 160) writes, mocking is a situation in which the author's voice "collides in a hostile fashion with the original owner and forces him to serve purposes diametrically opposed to his own".

The ambivalent nature of the Märät Säpikkäät/Nuoska Bittut television comedy show locates it within this realm of humour. However, the particular aesthetics employed in the show can be described as strategically commodified ambivalence. The controversial, open-ended show is characterised by irony, exaggerated parodies, and an observational yet tongue-in-cheek style. The ambivalence relates especially to the directionality and intentionality of the humour. There are plenty of possibilities in interpreting who is laughing at or with whom and at what (for more on the distinctions of laughing at and with see Glenn 2003). While there have been some concerns about issues such as good taste (cf. Bourdieu 1984 [1979], 6) and the appropriate ways to publicly represent Sámi issues, the show appeals to a 
"smart" niche audience who derive pleasure from their ironic cleverness and postmodern sensibilities and reflexivity. In the show, the figure that is being mocked is that of the fake Sámi whose act of using Sámi resources for tourist purposes is ridiculed and critically commented on. Jørgensen (2005) argues that in postmodern urban societies, members share different types of knowledge about a number of language varieties, including knowledge related to stereotypes of speakers of the different varieties. Such members then use this knowledge to create different effects. For performing humour, these facts can be drawn on as resources for sketching stereotypes.

\section{Acknowledgements}

We want to thank the two anonymous reviewers for their helpful comments and our colleagues Riikka Ullakonoja and Johanna Vaattovaara for their help with the phonetics and Lappish Finnish dialect descriptions. We also thank Nikolas Coupland who provided sights and expertise that greatly improved the manuscript. The work by Sari Pietikäinen was partly supported by Cold Rush: Dynamics of language and identity in emerging Arctic economics - project, funded by the Academy of Finland.

\section{References}

Aikio-Puoskari, Ulla. 2005. "The Education of the Sámi in the Comprehensive Schooling of Three Nordic Countries: Norway, Finland and Sweden.” Journal of Indigenous Peoples Rights 2.

Bakhtin, Mikhail. 1984 [1965]. Rabelais and His World, translated by Hélenè Iswolsky. Bloomington: Indiana University Press.

Bauman, Richard. 2011. "Commentary: Foundations in Performance." Journal of Sociolinguistics 15 (5): 707-720. doi:10.1111/j.1467-9841.2011.00510.x

Bauman, Richard, and Charles L. Briggs. 1990. "Poetics and Performance as Critical Perspectives on Language and Social Life." Annual Review of Anthropology 19: 59-88.

doi:10.1146/annurev.an.19.100190.000423

Bell, Allan, and Andy Gibson. 2011. "Staging Language: An Introduction to the Sociolinguistics of Performance." Journal of Sociolinguistics 15 (5): 555-572. doi: 10.1111/j.1467-9841.2011.00517.x Bourdieu, Pierre. 1984 [1979]. Distinction: A Social Critique of the Judgement of Taste. Translated in English by Richard Nice. Cambridge, U.S.: Harvard University Press.

Bucholtz, Mary. 2003. "Sociolinguistic Nostalgia and the Authentication of Identity." Journal of Sociolinguistics 7 (3): 398-416. doi:10.1111/1467-9481.00232

Bucholtz, Mary, and Kira Hall. 2005. "Identity and Interaction: A Sociocultural Linguistic Approach.” Discourse studies 7 (4-5): 585-614. doi:10.1177/1461445605054407

Bucholtz, Mary, and Qiuana Lopez. 2011. "Performing Blackness, Forming Whiteness: Linguistic Minstrelsy in Hollywood film.” Journal of Sociolinguistics 15 (5): 680-706.

doi: 10.1111/j.1467-9841.2011.00513.x 
Coupland, Nikolas. 2007. Style. Language variation and identity. Cambridge: Cambridge University Press. doi:10.1017/CBO9780511755064

Dlaske, Kati, and Saara Jäntti. 2016. "Girls Strike Back: The Politics of Parody in an Indigenous TV Comedy." Gender and Language 10 (2): 191-251.

Dufva, Hannele, and Mia Halonen. 2016. "Svetlana Rönkkö ja Tove Hansson: Vieraan aksentin performanssi mediahuumorin resurssina [Foreign accent as a resource for creating humour in media]". In Kielenkäyttäjä muuttuvissa instituutioissa [Language user in changing institutions], ed. by Anna Solin, Johanna Vaattovaara, Niina Hynninen, Ulla Tiililä, and Taru Nordlund, 145-162. AFinLAn vuosikirja [Yearbook of AFinLA.] Jyväskylä: Suomen The Finnish Association for Applied Linguistics.

Glenn, Philip. 2003. Laughter in Interaction. Cambridge: Cambridge University Press. doi: $10.1017 / C B O 9780511519888$

Goffman, Erving. 1981. "Footing.” In Forms of talk, 124-159. Oxford: Basil Blackwell.

Hill, Jane H. 1995. "Junk Spanish, Covert Racism, and the (Leaky) Boundary between Public and Private Spheres." Pragmatics 5 (2): 197-212. doi:10.1075/prag.5.2.07hil

Holm, Nicholas. 2011. Reassessing the Right to Laughter: Humour, Dissent and the Liberal Imagination. Victoria: Victoria University of Wellington. http://www.victoria.ac.nz/atp/ Accessed 30.11.2013

Hutcheon, Linda. 2000 [1985]. A theory of Parody: The Teachings of Twentieth-Century Art Forms. Urbana: University of Illinois Press.

Iivonen, Antti. 2009. "Major Features of Standard Finnish Phonetics." In Phonetics in Russian and Finnish, ed. by Viola de Silva, and Riikka Ullakonoja, 47-66. Frankfurt am Main: Peter Lang. Johnstone, Barbara. 2011. "Dialect Enregisterment in Performance." Journal of Sociolinguistics 15: 657-679. doi:10.1111/j.1467-9841.2011.00512.x

Jørgensen, Normann J. 2005. "Plurilingual Conversations among Bilingual Adolescents." Journal of Pragmatics 37 (3): 391-402. doi:10.1016/j.pragma.2004.10.009

Kramsch, Claire. 2012. "Imposture: A Late Modern Notion in Poststructuralist SLA Research." Applied Linguistics 33 (5): 483-502. doi:10.1093/applin/ams051

Kulonen, Ulla-Maija, Irja Seurujärvi-Kari, and Risto Pulkkinen (eds.). 2005. The Sámi: A Cultural Encyclopaedia. Helsinki: Finnish Literature Society.

Lehtola, Veli-Pekka. 2015. Saamelaiskiista [Sámi struggle]. Helsinki: Into kustannus.

Lockyer, Sharon. 2010. "Dynamics of Social Class Contempt in Contemporary British Television Comedy." Social Semiotics 20: 121-138. doi:10.1080/10350330903565758

Länsman, Anni-Siiri. 2004. Väärtisuhteet Lapin matkailussa: Kulttuurianalyysi suomalaisten ja saamelaisten kohtaamisesta [Host-guest relations in tourism in Sápmi (Finland). A cultural analysis of the encounter between Finns and Sámi]. Inari: Kustannus Puntsi.

Magga, Sigga-Marja. 2012. "Saamelainen käsityö duodji kansallisen identiteetin rakentajana." In Saamenmaa: kulttuuritieteellisiä näkökulmia [Sámiland: cultural scientific viewpoints], ed. by Veli-Pekka Lehtola, Ulla Piela, and Hanna Snellman, 216-225. Helsinki: Finnish Literature Society.

Mantila, Harri. 1992. Ei tääläkhän senthän jokhaisen sanhan hootakhan panna. Jälkitavujen vokaalienvälisen h:n variaatio peräpohjalaisissa murteissa [Variations of intervocalic $h$ in noninitial syllables in the dialects of Peräpohjola]. Helsinki: Finnish Literature Society.

McDonald, Paul. 2010. Laughing at the Darkness: Postmodernism and Optimism in American Humour. Penrith: Humanities-Ebooks. 
Mielikäinen, Aila, and Marjatta Palander. 2014. Miten suomalaiset puhuvat murteista?: Kansanlingvistinen tutkimus metakielestä [How Finns talk about dialects? Folklinguistic study of metalanguage]. Helsinki: Finnish Literature Society.

Mühleisen, Susanne. 2005. "What Makes an Accent Funny, and Why? Black British Englishes and Humour Televised." In Cheeky fictions: Laughter and the postcolonial, ed. by Susanne Reichl, and Mark Stein, 225-244. Amsterdam \& New York: Rodopi.

Niedzielski, Nancy A., and Dennis R. Preston. 2003. Folk Linguistics. Berlin: Mouton de Gruyter. Ogden, Richard. 2009. An Introduction to English Phonetics. Edinburgh: Edinburgh University Press.

Olsen, Lance. 1990. Circus of the Mind in Motion. Postmodernism and the Comic Vision. Detroit: Wayne State University Press.

Pietikäinen, Sari. 2014. "Circulation of Indigenous Sámi Resources across Media Spaces: A Rhizomatic Discourse Approach.” In Mediatization and Sociolinguistic Change, ed. by Jannis Androutsopoulos, 515-538. Berlin \& Boston: Walter de Gruyter.

Pietikäinen, Sari. 2015. "Multilingual Dynamics in Sámiland: Rhizomatic Discourses on Changing Language." International Journal of Bilingualism 19 (2): 206-225. doi:10.1177/1367006913489199

Pietikäinen, Sari, Helen Kelly-Holmes, Alexandra Jaffe, and Nikolas Coupland. 2016. Sociolinguistics from the Periphery. Small Languages in New Circumstances. Cambridge: Cambridge University Press.

Piller, Ingrid. 2002. "Passing for a Native Speaker: Identity and Success in Second Language Learning." Journal of Sociolinguistics 6: 179-206. doi:10.1111/1467-9481.00184

Pope, Rob. 1995. Textual Intervention: Critical and Creative Strategies for Literary Studies. London \& New York: Routledge.

Preston, Dennis R. 1996. “Whaddayaknow?: The Modes of Folk Linguistic Awareness.” Language Awareness 5: 40-74. doi:10.1080/09658416.1996.9959890

Preston, Dennis R. 2002. "Language with an Attitude." In Handbook of Language Variation and Change, ed. by J. K. Chambers, Peter Trudgill, and Natalie Schilling-Estes, 40-66. Oxford: Blackwell.

Preston, Dennis R. 2010. "Language, People, Salience, Space: Perceptual Dialectology and Language Regard.” Dialectologica 5: 87-131.

Pye, Gillian. 2006. "Comedy Theory and the Postmodern." Humour - International Journal of Humor Research 18: 53-70.

Rampton, Ben. 2006. Language in Late Modernity. Cambridge: Cambridge University Press. doi: $10.1017 / C B O 9780511486722$

Ronkin, Maggie, and Helen E. Karn. 1999. "Mock Ebonics: Linguistic Racism in Parodies of Ebonics on the Internet." Journal of Sociolinguistics 3: 360-380. doi:10.1111/1467-9481.00083

Sarivaara, Erika. 2012. Statuksettomat saamelaiset: Paikantumisia saamelaisuuden rajoilla [Non-status Sámi. Locations within Sámi borderlands]. Doctoral thesis. Guovdageaidnu: Sámiallaskuvla.

Sebba, Mark. 2007. "Identity and Language Construction in an Online Community: The Case of 'Ali G'”' In Social Identity and Communicative Styles - An Alternative Approach to Linguistic Variability, ed. by Peter Auer, 361-392. Berlin: Mouton de Gruyter.

Silverstein, Michael. 2003. "Indexical Order and the Dialectics of Sociolinguistic Life." Language \& Communication 23: 193-229. doi:10.1016/S0271-5309(03)ooo13-2

'Tankero', Finnish Wikipedia in Finnish and English http://fi.wikipedia.org/wiki/Tankerohttp:// en.wikipedia.org/wiki/Tankero Accessed in 15.12.2014. 
Vaattovaara, Johanna. 2012. "Making Sense of Space: On Dialect Production and Perception at the Finland-Sweden Border.” In Dialectological and Folk Dialectological Concepts of Space: Current Methods and Perspectives in Sociolinguistic Research on Dialect Change, ed. by Sandra Hansen, Christian Schwarz, Philipp Stoeckle, and Tobias Streck, 119-141. Berlin: Mouton de Gruyter.

Vaattovaara, Johanna, and Mia Halonen. 2015. "Missä on ässä? "Stadilaisen s:n" helsinkiläisyydestä [About the nature of 'Stadi s' in spoken language in Helsinki]." In Helsingissä puhuttavat suomet: Kielen indeksisyys ja identiteetit [Helsinki Finnishes: Indexicality and identities], ed. by Marja-Leena Sorjonen, Anu Rouhikoski, and Heini Lehtonen, 40-83. Helsinki: Finnish Literature Society.

\section{Appendix. Transcript of the fake Sámi skit}

\section{Scene 1. Selling the reindeer antler powder}

Action scene:

01 Fake Sámi: Mie olen Saana $\mathrm{t}^{\mathrm{h}}$ yttö tunturist ${ }^{\mathrm{h}} \mathrm{a}$. Mie elän .hh porojen $\mathrm{k}^{\mathrm{h}}$ anssa $\mathrm{k}^{\mathrm{h}}$ odassa. I am Saana, a girl from the fell. I live in a tepee with reindeers

Commentator voice-over:

02 Feikkisaamelainen edustaa saamelaisia missikisoissa turistirysissä A fake Sámi represents the Sámi in beauty contests in tourist traps

03 kisatyttönä tai matkamessuilla. as a grid girl or at travel fairs.

04 Feikkisaamelainen naamioituu saamelaiseksi asulla joka on mielivaltainen A fake Sámi dresses as a Sámi person in a costume which is a random

05 sekoitus eri alueen saamen pukuja ja muistuttaa lähinnä oksennusta. combination of different regions' Sámi costumes and mainly resembles vomit.

06 Naisfeikkissaamelaisella on päässään miesten neljän tuulen lakki A female fake Sámi wears men's Four Wings cap

07 ja hän tykkää joikata varsinkin jos joku turisti siitä maksaa and she likes to joik, especially if some tourist pays for it.

Action scene:

08 Fake Sámi: Fifty euros, buy.

09 Tourist: $\quad$ No. ((Shakes his head.))

10 Fake Sámi: Potency. Mycket ['much' in Swedish] potency. Sámi mystical powder.

Commentator voice-over:

11 Hänen työnsä on myydä ohjelmapalveluna Lapin kaste tai poroajelu. Her job is to sell tour packages such as a Lappish baptism or reindeer sledding. 
Action scene:

12 Fake Sámi: Lapin kaste.

Lappish baptism ritual. ((Talks to the tourist.))

13 Tourist: [ten euro]

ten euros

14 Fake Sámi: [o:ko: ten ten euro]

Okay, ten, ten euros.

Commentator voice-over:

15 Päätyönään hän myy poronsarvijauhetta.

Her main source of income is selling reindeer antler powder.

Action scene:

16 Fake Sámi: Lucky woman, lucky woman. This [tis] mystical powder. Sámi viriliti. ((Talks to the woman who is with the tourist.))

Scene 2. Mock interview ((F is "answering"; the questions are not heard))

Action scene.

17 Fake Sámi: No kyllä näiden symbolien käyttö on ihan jokamiehen oikeus et kyllä miWell, using these symbols is everyman's right, so I ((the speech fades out))

Commentator voice-over:

18 Feikkisaamelainen puolustaa kiivaasti oikeuttaan näytellä saamelaista.

A fake Sámi fiercely defends her right to play Sámi.

19 Tästäkin syystä feikkisaamelainen saattaa olla harmillinen tyyppi

Also for this reason a fake Sámi may be a harmful figure.

Scene 3. The tourist performance continues

Action scene:

20 Fake Sámi: $\quad \mathrm{T}^{\mathrm{h}}$ iina $\mathrm{t}^{\mathrm{h}} \mathrm{yttö} \mathrm{t}^{\mathrm{h}}$ unthrist $\mathrm{t}^{\mathrm{h}} \mathrm{a}$.

Tiina - girl from the fell.

21

$\mathrm{K}^{\mathrm{h}}$ un me $\mathrm{s}^{\mathrm{h}}{ }^{\mathrm{uut}}{ }^{\mathrm{h}} \mathrm{umme}$ me $\mathrm{k}^{\mathrm{h}}$ iroamme $\mathrm{k}^{\mathrm{h}}$ aikki vihollis ${ }^{\mathrm{h}}$ emme.

When we get angry we put a spell on all our enemies 


\section{Authors' addresses}

\section{Mia Halonen}

Centre for Applied Language Studies

University of Jyväskylä

P.O. Box B 35

40014 University of Jyväskylä

Finland

mia.m.halonen@jyu.fi

\section{Sari Pietikäinen}

Department of Language and Communication Studies

University of Jyväskylä

P.O. Box B 35

40014 University of Jyväskylä

Finland

sari.p.pietikainen@jyu.fi 